\title{
Selection of Aluminum Matrix for Boron-Aluminum Sheet Alloys
}

\author{
N.A. Belov, K. Yu. Chervyakova and M.E. Samoshina
}

\begin{abstract}
The problem of substantiating the aluminum matrix composition for obtaining the hardenable by heat-treatment boron-aluminum alloys in the form of ingots and sheet products. Alumanation materials alloyed by boron are promising radiation-resistant structural materials. Analysis of basic systems of the hardenable by heat-treatment aluminum alloys was carried out. With the use of the calculations (Thermo-Calc software) and experimental methods (including scanning electron microscopy and microprobe analysis), justified has been an unreasonableness of obtaining the boron-aluminum alloys based on magnesium-containing systems because of an active interaction of that element with boron. An experimental study has been focused on the boron-aluminum alloys based on $\mathrm{Al}-\mathrm{Zr}-\mathrm{Sc}$ (with magnesium, manganese and titanium additives) and $\mathrm{Al}-\mathrm{Cu}$ systems. It was found that titanium introduction into the systems with zirconium and scandium does not assist in preventing their interaction with boron, which hampers the aluminum matrix hardening. The $\mathrm{Al}-\mathrm{Cu}$ system meets the requirements best of all since copper doesn't interact with boron and does not affect on composition of the boron-containing phases. It was determined that such system allows to obtain ingots and sheet products of aluminum boron-containing alloy possessing high mechanical properties. The maximum achievable hardness on ingots and sheet products amounts to $\sim 130 \mathrm{HV}$, and the tensile strength (sheet) equals to $430 \mathrm{MPa}$.
\end{abstract}

Keywords Boron-Aluminum - Sheet products - Microstructure

Phase diagrams $\cdot$ Heat treatment $\cdot$ Mechanical properties $\cdot$ Hardness

N.A. Belov $\cdot$ K.Yu. Chervyakova $\cdot$ M.E. Samoshina $(\bowtie)$

Department of Casting Process Technology, National University of Science and Technology,

Moscow, Russia

e-mail: samoshina@list.ru

(C) The Author(s) 2018

K.V. Anisimov et al. (eds.), Proceedings of the Scientific-Practical Conference

"Research and Development - 2016", https://doi.org/10.1007/978-3-319-62870-7_47 


\section{Introduction}

Today, the boron-doped materials are considered as promising radiation-resistant structural materials for use in different fields: atomic engineering industry, at aerospace enterprises, in several lines of electrical engineering, instrument-making industry and electronics $[1$, p. $1109 ; 2$, p. 358]. The field-performance data of this class of materials should meet very high requirements. In addition to the capability for absorbing thermal neutrons, corrosion resistance, thermal conductivity, boronaluminum materials should possess high mechanical properties [3, p. 52; 4, p. 470].

Abroad, the volume of production with the use of the boron-filled materials measures by many tens thousands ton per year. Lately, the liquid-phase technologies of boron-aluminum production become widely (in particular, in the form of ingots meant for sheet products making thereof), since they often are essentially cheaper, technologically simpler and guarantee high mechanical properties of materials owing to the strong connection on the matrix-filler border. Some companies producing boron-aluminum use a mixing technology of powder particles of the boron-containing compounds (for example, $\mathrm{B}_{4} \mathrm{C}$ ) into liquid smelt [5]. In Russia, the wide production of boron-containing aluminum alloys is lacking until now, notwithstanding the fact that a need for them is evidently felt. Specifically, during transportation of proceeded radioactive wastes, the transit of which is currently carried out in the old-type containers made of the boron-filled steel.

Using binary Al-B alloys as an example, in the paper [6, p. 24] it is shown that borides do not make unalloyed aluminum manufacturability worse during cold rolling. However, the strength of the binary boron-aluminum alloys (without additional doping) is not high. To obtain the required mechanical properties (the strengthening ones first of all), an additional doping is necessary [7, p. 647].

It is known that one can gain the highest strength in aluminum alloys due to forming of the nano-sized particles, especially in the aging process [8, p. 208; 9 , p. 42]. The main problem of obtaining the boron-aluminum with increased strength is caused by the fact that boron actively interacts with many elements, such as magnesium [10, p. 90], titanium [11], zirconium and scandium [8, p. 391; 12, p. 40]. That is why the optimum concentrations of introduced elements may essentially differ from the compositions of grade alloys, which can provide the desired level of properties on their own (that is without boron).

From the above reasoning, the objective of the present paper was a substantiation of an aluminum matrix composition for obtaining the hardenable by heat-treatment boron-aluminum alloys obtained in the form of ingots and sheet products with the strength level above $300 \mathrm{MPa}$. 


\section{Analysis of Basic Systems of the Hardenable by Heat-Treatment Aluminum Alloys}

The main basic systems of the hardenable by heat-treatment aluminum alloys are $\mathrm{Al}-\mathrm{Cu}$ (reinforcing phase $\mathrm{Al}_{2} \mathrm{Cu}-\Theta^{\prime}, \Theta^{\prime \prime}$ ), $\mathrm{Al}-\mathrm{Cu}-\mathrm{Mg}$ (reinforcing phase $\mathrm{Al}_{2} \mathrm{CuMg}-S^{\prime}$ ), $\mathrm{Al}-\mathrm{Mg}-\mathrm{Si}$ (reinforcing phase $\mathrm{Mg}_{2} \mathrm{Si}-\beta^{\prime}, \beta^{\prime \prime}$ ), Al-Zn-Mg (reinforcing phase $\mathrm{Al}_{2} \mathrm{Mg}_{3} \mathrm{Zn}_{2}-\tau^{\prime}, \quad \tau^{\prime \prime}$ and $\mathrm{MgZn}_{2} \eta^{\prime}, \quad \eta^{\prime \prime}$ ), $\mathrm{Al}-\mathrm{Mg}-\mathrm{Si}-\mathrm{Cu}$ (reinforcing phase $\mathrm{Al}_{5} \mathrm{Cu}_{2} \mathrm{Mg}_{8} \mathrm{Si}_{6}-Q^{\prime}$ ), $\mathrm{Al}-\mathrm{Zn}-\mathrm{Mg}-\mathrm{Cu}$ (reinforcing phase $\mathrm{AlCuMgZn}-T$ and $\mathrm{AlCuMgZn}-M), \mathrm{Al}-\mathrm{Zr}-\mathrm{Sc}$ (reinforcing phase $\left.\mathrm{Al}_{3}(\mathrm{Zr}, \mathrm{Sc})-\mathrm{L1}_{2}\right)$.

Inasmuch as high temperatures of the smelt are required for the boron-aluminum alloys preparing [6, p. 24], the systems containing zinc and magnesium seem to be unwanted because of significant losses during the melting process. Interaction of this element with boron can also be considered as a weakness of the systems with magnesium in composition. In particular, in the paper [10, p. 90] it is shown that achievement of necessary reinforcement in a boron-containing alloy based on $\mathrm{Al}-$ $\mathrm{Mg}-\mathrm{Si}-\mathrm{Cu}$ matrix required the doubled magnesium concentration in comparison with 6xxx grade alloys. Nevertheless, alloys based on this system are used in a number of developments (for example, in [13]).

In Fig. 1 isothermal sections of $\mathrm{Al}-\mathrm{B}-\mathrm{Mg}$ and $\mathrm{Al}-\mathrm{B}-\mathrm{Cu}$ systems at $1100{ }^{\circ} \mathrm{C}$ are represented. It is known that there is a continuous series of solid solutions between $\mathrm{AlB}_{2}$ and $\mathrm{MgB}_{2}$ borides in an $\mathrm{Al}-\mathrm{B}-\mathrm{Mg}$ system [14, p. 92]. Therefore, an $(\mathrm{Al}, \mathrm{Mg}) \mathrm{B}_{2}$ compound with particles of adverse needle-shaped form arises even at small magnesium concentrations, as shown in Fig. 1a [6, p. 24]. On the other side, copper is completely in the melt, as it appears from Fig. 1b. Hence, only two basic systems remain for obtaining the hardenable by heat-treatment boron-aluminum alloys, namely: $\mathrm{Al}-\mathrm{Cu}$ and $\mathrm{Al}-\mathrm{Zr}-\mathrm{Sc}(+\mathrm{Mg}, \mathrm{Mn})$. The selection of the latter is based on the paper [4, p. 470].
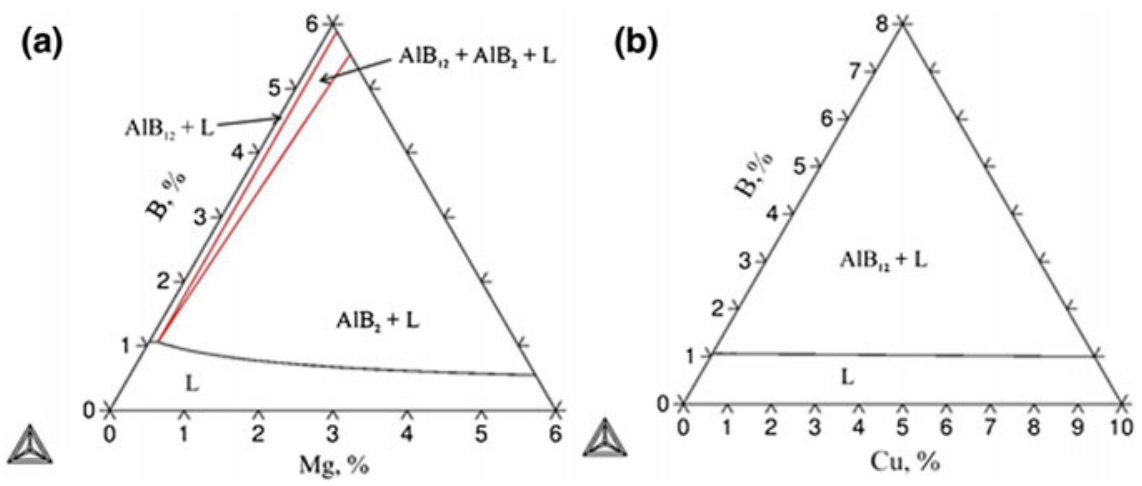

Fig. 1 Isothermal sections of ternary systems at $1100{ }^{\circ} \mathrm{C}$ : $\mathrm{Al}-\mathrm{B}-\mathrm{Mg}(\mathbf{a}) \mathrm{Al}-\mathrm{B}-\mathrm{Cu}(\mathbf{b})$ (calculation by Thermo-Calc software) 


\section{Experimental Procedures}

The main subjects of experimental investigation were the boron-aluminum alloys based on $\mathrm{Al}-\mathrm{Zr}-\mathrm{Sc}$ (+ additives) and $\mathrm{Al}-\mathrm{Cu}$ matrix systems.

Alloys have been prepared based onhigh-purity aluminum A99 $(99.99 \% \mathrm{Al})$ and Al-5\% B master alloy. Copper and magnesium have been introduced in pure form $(99.9 \% \mathrm{Mg}$ and $99.9 \% \mathrm{Cu}$ respectively), titanium has been introduced in the form of T80F20 alloying tablets, the resting elements have been introduced as Al-2\%Sc, $\mathrm{Al}-10 \% \mathrm{Zr}, \mathrm{Al}-10 \% \mathrm{Mn}$ master alloys. Melting has been carried out in a graphite-fireclay crucible at the temperature of $900-950{ }^{\circ} \mathrm{C}$ in a RELTEK induction furnace, which provides an intensive melt mixing, required to exclude a possibility of refractory boron-containing particles deposition. The master alloy and melting technology have been selected taking into account the results of the previously fulfilled experiments $[6$, p. 24]. The melt was poured into a graphite molds to obtain flat ingots of $40 \times 120 \times 200 \mathrm{~mm}$ in size, Fig. 2a. Samples for structural investigations have been cut thereof. Later on, the ingots have been treated by strain processing to a thickness of $0.3 \mathrm{~mm}$, Fig. $2 \mathrm{~b}$ [6, p. 24].

Experimental alloys have been investigated both in cast condition and after thermal treatment, carried out with the use of a SNOL 8,2/1100 muffle electric furnace and a SNOL 58/350 low-temperature laboratory electric furnace.

Polished sections were prepared by mechanical polishing. Primary microstructure analysis of samples has been fulfilled on an Axio Observer MAT optical microscope, whereas the detailed metallographic research has been conducted on a TESCAN VEGA 3 scanning electron microscope (SEM). The TESCAN microscope, completed by an energy dispersive microanalyser device manufactured by Oxford Instruments and Aztec software, has also be used for the electro-microprobe analysis (EMPA).

The Thermo-Calc program (with a TCAL4 database) has been used for calculating phase composition of the systems [15].

The hardness has been measured on a NEMESIS 9000 multi-purpose hardometer made by INNOVATEST. In order to determine mechanical properties (rupture strength UTS, yield stress 0.2YS and elongation El), an uniaxial tension testing has been conducted on a Zwick Z250 tearing machine.

(a)

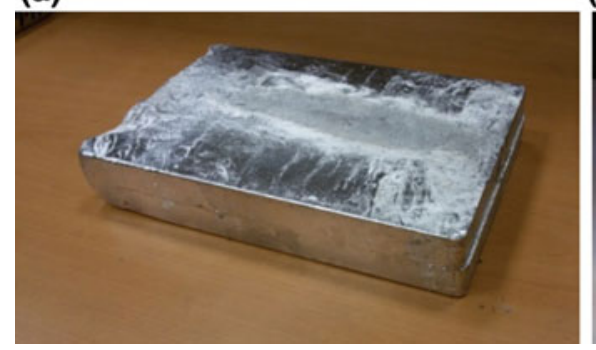

(b)

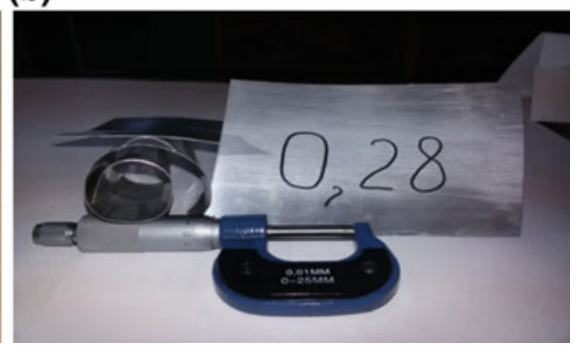

Fig. 2 General form: ingot (a), sheet products (b) 


\section{Results and their Examination}

Composition of alloy $\mathrm{Al}-2 \% \mathrm{Mn}-0.25 \% \mathrm{Zr}-0.1 \% \mathrm{Sc}$ has been chosen relying on papers $[8$, p. 369; 16; 17] its heat resistance and high mechanical properties of $\mathrm{Al}-2 \% \mathrm{Mn}-0,25 \% \mathrm{Zr}-0,1 \% \mathrm{Sc}$ basic alloys are conditioned by the fact that the doping elements form $\mathrm{Al}_{6} \mathrm{Mn}$ and $\mathrm{Al}_{3}(\mathrm{Zr}, \mathrm{Sc})$ dispersoids, possessing high thermal stability. However, as it follows from the paper [4, p. 470], zirconium and scandium interacts with boron. To avoid losses of these elements, titanium has been introduced, suggesting its interaction with the boron for $\mathrm{a} \mathrm{TiB}_{2}$ compound formation as a result. An $\mathrm{Al}-4 \% \mathrm{Mg}-1 \% \mathrm{Mn}-2 \% \mathrm{~B}-1.5 \% \mathrm{Ti}-0.3 \% \mathrm{Sc}$ alloy containing scandium only has been complimentary examined after both introducing magnesium to guarantee an additional reinforcement of alloy due to the rise of the solid solution hardness and the scandium content increasing for providing a dispersion hardening.

In the alloys microstructure primary crystals of zirconium with manganese are distinguished. In addition to the aluminum solid solution, presence of $\mathrm{ZrB}_{2}, \mathrm{TiB}_{2}$, and $\mathrm{Al}_{6}(\mathrm{Fe}, \mathrm{Mn})$ phases has been revealed by X-ray phase analysis. In spite of titanium presence in the composition, zirconium interacts with the boron. Studies of composition of aluminum matrix of the melt have shown that it practically does not contain other elements except Mn. Obviously, high mechanical properties and heat resistance could not be achieved with such a structure by means of zirconium additives.

It is evident from the theoretical calculation of quantitative phase analysis of the Al-2\%Mn- $0.25 \% \mathrm{Zr}-0.1 \% \mathrm{Sc}-1.5 \% \mathrm{Ti}-2 \% \mathrm{~B}$ alloy that all doping components interact with the boron except scandium. Only manganese and noninteracting with the boron scandium are resting in an aluminum solid solution at the temperature of $655{ }^{\circ} \mathrm{C}$.

Measuring hardness of the samples under consideration has shown that the basic alloy gets an increased hardness after heterogenizing annealing, though alloys with the boron additives do not become reinforced. This is connected with the boron interaction with zirconium and scandium, which leads to the lack of these elements in a quantity required to form the reinforcing phases.

Thus, the introduction of small addition of boron negatively effects on capability of alloys, containing zirconium and scandium, for a precipitation strengthening. In [4, p. 470] there is considered a process of boron-aluminum obtaining when the boron has been introduced in the form of $\mathrm{B}_{4} \mathrm{C}$, with the increased zirconium and scandium content. The obtained result meets the requirements upon high mechanical properties, but the redundant introduction of zirconium and scandium results in a rise in the cost of the produced material.

Hence, the $\mathrm{Al}-\mathrm{Cu}$ system rests the only one to be considered. It is evident from the calculations of the quantitative phase analysis of the $\mathrm{Al}-6 \% \mathrm{Cu}-2 \% \mathrm{~B}$ alloy that three phases are observed in the microstructure, but for all that copper does not interact with boron and is contained in a solid aluminum solution (or smelt) and in an $\mathrm{Al}_{2} \mathrm{Cu}$ compound.

Study on the $\mathrm{Al}-6 \% \mathrm{Cu}-2 \% \mathrm{~B}$ alloy microstructure shows a uniform distribution of $\mathrm{AlB}_{12}$ boride particles, crystals of which do not exceed $30 \mu \mathrm{m}$ (Fig. 3a). 
(a)

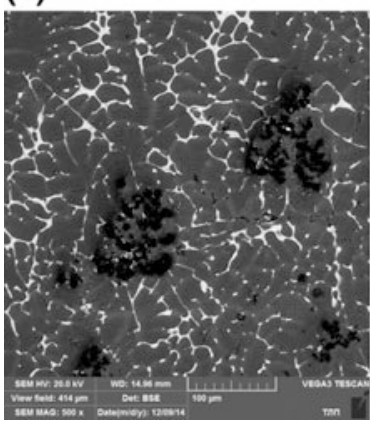

(b)

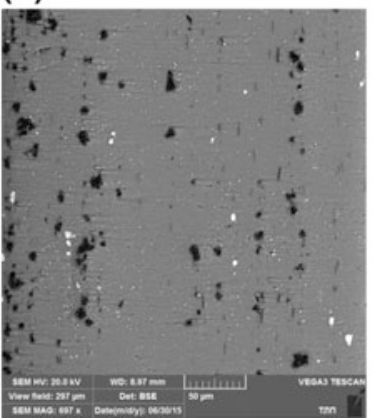

(c)

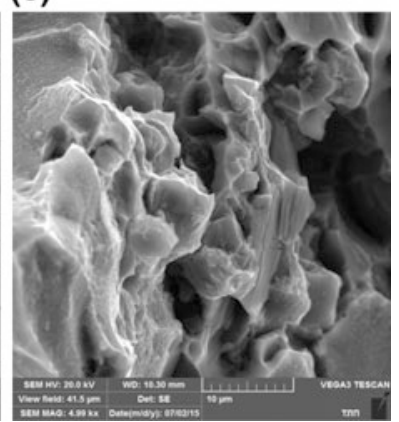

Fig. 3 Images of microstructure of $\mathrm{Al}-6 \% \mathrm{Cu}-2 \% \mathrm{~B}$ alloy on a scanning electron microscope: ingot (a) Sheet products $(\mathbf{b}, \mathbf{c})$ Polished samples $(\mathbf{a}, \mathbf{b})$ Fractogram (c)

The needle-shaped impurities of $\mathrm{AlB}_{2}$ are observed in a small proportion (as in a source master alloy [6, p. 24]). In the structure, there are revealed light $\mathrm{Al}_{2} \mathrm{Cu}$ streaks of eutectic origin, which are well observable in fractograms (Fig. 3c).

Annealing at $540{ }^{\circ} \mathrm{C}$ doesn't affect the morphology and composition of borides. The main part of $\mathrm{Al}_{2} \mathrm{Cu}$ from a non-equilibrium eutectic has been dissolved in ( $\mathrm{Al}$ ); the remaining impurities have been shaped into a globular form.

Strengthening level has been estimated on the ingots after applying various heat treatment conditions. As one can see in Fig. 4a, the maximum value of hardness is observed at the aging temperature of $180-210{ }^{\circ} \mathrm{C}$. With the temperature increase, a softening (or overaging) takes place. Studying on the strengthening level on the sheet products (Fig. 4b) has confirmed the results obtained on the ingots.

(a)

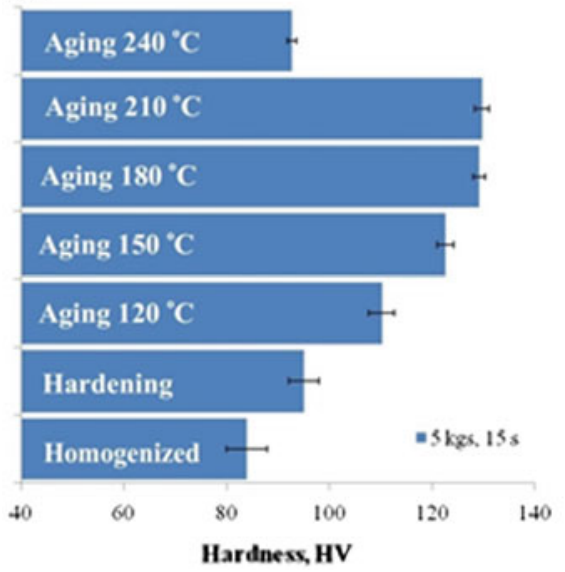

(b)

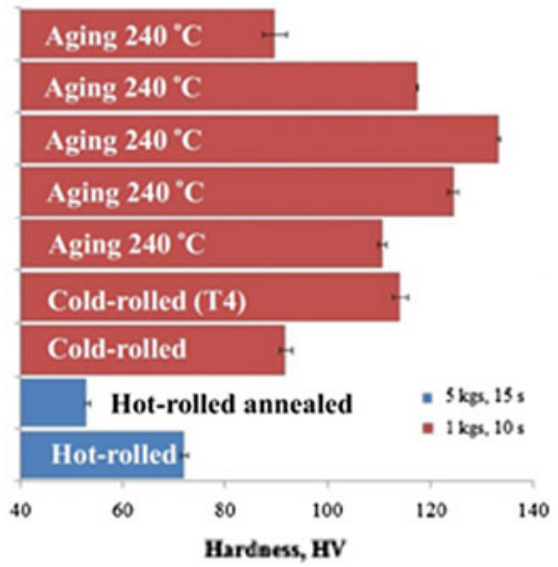

Fig. 4 Ingots (a) and sheet products (b) of $\mathrm{Al}-6 \% \mathrm{Cu}-2 \% \mathrm{~B}$ alloy hardness dependence of a heat-treatment mode 
Table 1 Mechanical properties of the Al-6\%Cu-2\%B alloy sheet products

\begin{tabular}{l|l|l|l}
\hline Aging temperature & $0.2 \mathrm{YS}, \mathrm{MPa}$ & UTS, MPa & El, \% \\
\hline $\mathrm{T} 4$ (hardening and natural aging) & $241 \pm 6$ & $368 \pm 5$ & 10.2 \\
\hline $120{ }^{\circ} \mathrm{C}, 3 \mathrm{~h}$ & $255 \pm 8$ & $357 \pm 9$ & 7.8 \\
\hline $150{ }^{\circ} \mathrm{C}, 3 \mathrm{~h}$ & $287 \pm 6$ & $401 \pm 11$ & 8.9 \\
\hline $180{ }^{\circ} \mathrm{C}, 3 \mathrm{~h}$ & $307 \pm 2$ & $430 \pm 14$ & 9.5 \\
\hline $210{ }^{\circ} \mathrm{C}, 3 \mathrm{~h}$ & $270 \pm 4$ & $379 \pm 8$ & 8.4 \\
\hline $240{ }^{\circ} \mathrm{C}, 3 \mathrm{~h}$ & $206 \pm 3$ & $289 \pm 13$ & 6.4 \\
\hline
\end{tabular}

Testing on uniaxial tension has showed high strength properties (Table 1), achievable by forming the nanoscale phases as a result of heat treatment.

\section{Conclusions}

Systems of the hardenable by heat-treatment aluminum alloys have been analyzed with reference to obtaining the boron-aluminum alloys on their base. There were indicated the weaknesses of traditional systems containing magnesium and zinc as well as of those containing zirconium and scandium.

It has been found experimentally that introducing zirconium and scandium additives to the boron-aluminum alloys is inexpediently for these elements form primary crystals, which practically completely remove them from the composition of the solid aluminum solution.

It was shown that the most promising matrix which can be used as a base for obtaining the boron-aluminum alloys is an $\mathrm{Al}-\mathrm{Cu}$ system, since copper does not interact with boron and that permits to achieve the same hardening as that of the grade alloys of a AA2219 type.

Using a model $\mathrm{Al}-6 \% \mathrm{Cu}-2 \% \mathrm{~B}$ alloy as an example, it was shown that the alloying system under review allows reaching a combination of high manufacturability during rolling and high mechanical properties, including that after the heating at $210{ }^{\circ} \mathrm{C}$.

Acknowledgements This article was written within the implementation of the Agreement on subsidies between the National University of Science and Technology "MISiS" and the Ministry of Education and Science of the Russian Federation within the framework of realization of the Federal Target Program "Research and Development in the Priority Directions of Progress of the Scientific and Technological Complex of Russia for 2014-2020", approved by the Decree of the Government of the Russian Federation of November 28, 2013, No. 1096. Agreement No. 14.578.21.0004. Unique identifier of the project RMEF157814X0004. 


\section{References}

1. Eichler, J., Lesniak, C.: Boron nitride (BN) and BN composites for high-temperature applications. J. Eur. Ceram. Soc. 28, 1105-1109 (2008)

2. Peng, Z., Yuli, L., Wenxian, W., Zhanping, G., Baodong, W.: The design, fabrication and properties of $\mathrm{B}_{4} \mathrm{C} / \mathrm{Al}$ neutron absorbers. J. Nucl. Mat. 437, 350-358 (2013)

3. Mohantya, R.M., Balasubramaniana, K., Seshadrib, S.K.: Boron carbide-reinforced alumnium 1100 matrix composites: fabrication and properties. Mat. Sci. Eng. A. 498, 42-52 (2008)

4. Lai, J., Zhang, Z., Chen, X.-G.: The thermal stability of mechanical properties of Al-B4C composites alloyed with $\mathrm{Sc}$ and $\mathrm{Zr}$ at elevated temperatures. Mat. Sci. Eng. A. 532, 462-470 (2012)

5. Skibo, M.D., Schuster, D.M., Bruski, R.S.: Apparatus for continuously preparing castable metal matrix composite material. Patent USA, No. 5531425. F27D27/00, B22D11/11, B01F7/16, C22C32/00, F27D3/00, C22C1/10, B22D1/00, C22C1/00. Patent holder: Alcan Aluminum Corporation. Asserted 07.02.1994. Published 02.07.1996

6. Samoshina, M.E., Belov, N.A., Alabin, A.N., Chervyakova, K.Yu.: Struktura i mekhanicheskiye svoystva listovogo prokata iz splava Al-3\% B, poluchennogo zhidkofaznym metodom (Structure and mechanical properties of alloy $\mathrm{Al}-3 \% \mathrm{~B}$ flats, obtained by liquid-phase method). Tsvetn. Met. Non-Ferrous Met. 10, 19-24 (2015)

7. Ömer, S., Ramazan, K.: Production and wear properties of metal matrix composites reinforced with boride particles. Mat. Des. 51, 641-647 (2013)

8. Belov, N.A.: Fazovyy sostav promyshlennykh i perspektivnykh alyuminievykh splavov (Phase Composition of Industrial and Prospective Aluminium Alloys). Publishing House of "MISiS", Moscow, (2010). $511 \mathrm{p}$

9. Mondolfo, L.F.: Struktura i svoystva alyuminievykh splavov (Aluminium Alloys: Structure and Properties) Translated from English. Moscow : Metallurgiya, (1979), $640 \mathrm{p}$

10. Kurbatkina, E.I., Belov, N.A., Alabin, A.N., Sidun, I.A.: Osobennosti plavki i litiya bor-soderzhashchikh alumomatrichnykh kompositov na osnove splavov 6xxx serii (Peculiarities of melting and casting of boron-containing aluminum-matrix composites based on 6xxx alloys). Tsvetn. Met. Non-Ferrous Met. 1, 85-90 (2015)

11. Chen, X.-G., Dube, G., Steward, N.: Neutron absorption effectiveness for boron content aluminum materials. Patent US, No. 20080050270. G21F 1/08, C22B 21/00, C22C 21/00, C22C 32/00. Assertes 21.04.2005. Published 12.06.2007

12. Alabin, A.N., Belov, N.A., Tabachkova, N.Yu., Akopyan, T.K.: Heat resistant alloys of Al$\mathrm{Zr}-\mathrm{Sc}$ system for electrical applications: analysis and optimization of phase composition. Non-ferrous Met. 2, 36-40 (2015)

13. Aruga, Y., Kajihara, K., Sugizaki, Y.: Aluminum base alloy containing boron and manufacturing method thereof. Patent US. No. 7125515. B22D 30/00, C22F 1/04. Asserted 15.04.2003. Published 24.10.2006

14. Belov, N.A., Samoshina, M.E., Alabin, A.N., Chervyakova, K.Yu.: Vliyanie medi i magniya na strukturu i fazovyi sostav slitkov boraluminiya (Copper and magnesium effect on structure and phase composition of boron-aluminum ingots). Met. Met. 1, 86-92 (2016)

15. Information at www.thermocalc.com

16. Alabin, A.N., Belov, V.D., Belov, N.A., Mishurov, S.S.: Termostoykiy liteynyi aluminievyi splav (Heat-resistant casting aluminum alloy). Patent RF, No. 2478131. IPC B82B 3/00, C22C 21/06. Patent holder: National University of Science and Technology "MISiS". Asserted 29.10.2010. Published 27.03.2012

17. Belov, N.A., Alabin, A. N. Termostoykiy splav na osnove aluminiya i sposob polucheniya iz nego deformirovannykh polufabrikatov (Aluminum base heat-resistant alloy and strained half-finished product manufacturing method thereof). Patent RF, No. 2446222. IPC C22C 21/14, C22F 1/057. Patent holder: National University of Science and Technology "MISiS". Asserted 29.10.2010. Published 27.03.2012 
Open Access This chapter is licensed under the terms of the Creative Commons Attribution 4.0 International License (http://creativecommons.org/licenses/by/4.0/), which permits use, sharing, adaptation, distribution and reproduction in any medium or format, as long as you give appropriate credit to the original author(s) and the source, provide a link to the Creative Commons license and indicate if changes were made.

The images or other third party material in this chapter are included in the chapter's Creative Commons license, unless indicated otherwise in a credit line to the material. If material is not included in the chapter's Creative Commons license and your intended use is not permitted by statutory regulation or exceeds the permitted use, you will need to obtain permission directly from the copyright holder.

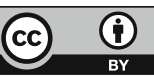

